\title{
The Home State Effect on Lobbying: Evidence from U.S. Climate Politics
}

\author{
Jonas Meckling and Samuel Trachtman* \\ University of California, Berkeley
}

Organized business interests often seek to block public interest regulations, but how they engage depends on institutional context. We argue that in federal systems state policy and politics can have a home state effect on firm preferences and political behavior at the national level. State policies can force firms to absorb regulatory cost, thus reducing the marginal cost of national policies. In addition, firms regulated at the state level have incentives to strategically align with their state governments to avoid future regulatory cost. We test our argument by matching original data on the positions of electric utilities towards the Clean Power Plan and data on ad hoc coalition membership with data measuring state policy stringency and state government positions. Quantitative evidence is consistent with hypotheses: both state policies and state politics influence utilities' national positions. Elite interviews clarify different mechanisms. Findings underscore how sub-national governments shape national interest group politics.

\footnotetext{
* Jonas Meckling (meckling@berkeley.edu) is an Associate Professor in the Department of Environmental Science, Policy, and Management at the University of California, Berkeley.

Samuel Trachtman (sam.trachtman@berkeley.edu) is a PhD Candidate in the Travers Department of Political Science at University of California, Berkeley. The authors contributed equally. This paper was prepared for the annual meeting of the American Political Science Association, September 2020.
} 


\section{Introduction}

The preferences of organized business interests are among the strongest drivers of policy decisions in American politics (Gilens and Page 2014). The opposition of business interests has been a crucial impediment to the advancement of federal policies to provide public benefits across a broad range of policy fields, including labor, environmental, and health policy (Layzer 2012; Hacker and Pierson 2002). At the same time, business coalitions opposing public interest regulation have sometimes split as firms join alliances advocating for policy reform (Swenson 2018). The emergence of competing business coalitions has been particularly important in climate politics, an increasingly salient field of American politics (S.E. Kim, Urpelainen, and Yang 2015; Downie 2017).

A long tradition of analysis has highlighted the role of economic factors in driving variation in firm preferences. Broadly speaking, prevailing explanations posit that firm preferences flow from firms' assets and how these are impacted by policies (Alt et al. 1999). Research on climate politics echoes these findings on economic factors. Firms that are more reliant on fossil fuel intensive assets or processes are more likely to actively seek to block policies that would mitigate climate change by reducing greenhouse gas emissions (Meckling 2015). Recent scholarship has added nuance to these explanations, broadening explanatory factors from firm assets and business models to trade exposure of polluting sectors (Genovese 2019), competitive dynamics vis-à-vis other producers (Kennard 2020), and embeddedness in fossil fuel supply chains (Cory, Lerner, and Osgood 2020).

Another strand of literature argues that these purely economic variables are insufficient to explain how firms engage in politics, highlighting instead the importance of political institutions (Martin and Swank 2012; Martin 1995; Woll 2009; Hacker and Pierson 2002). Extending this work, we propose that the institution of federalism can shape the political engagement of firms. More specifically, we propose a home state effect. In federal political systems like the U.S., state policy and politics can affect firms' national-level preferences and coalition membership.

The core mechanism we identify by which state policies can affect firms' national positions is cost absorption. State policies might force firms to shift investments and operations, and absorb costs, in order to comply. These shifts, in turn, can affect firms' positions vis-à-vis potential federal policies. The core rationale by which state politics can affect firms' national positions is cost avoidance. More specifically, firms principally regulated at the state level might strategically align positions with their home state governments to maintain or win political capital that helps them avoid future regulatory cost.

We examine our argument in the case of the position-taking and coalition membership of electric utilities in U.S. federal climate politics. Electric utilities have historically been core opponents of climate policy advances in the U.S. (Brulle 2018). But electric utilities increasingly vary in their national positions. This is a suitable case, in addition, because of the growing variation in state policy landscapes. State climate policy has grown more polarized: some states 
have expanded their policies significantly, while others never adopted policies in the first place or retrenched (Stokes 2020; Trachtman 2020a). To what extent is the variation in electric utilities' positions explained by variation in the policy and political environments in which they operate?

Our first quantitative analysis examines the positions of electric utilities with respect to litigation challenging the Clean Power Plan (CPP). Leveraging a novel data set linking state policy, electric utility attributes, and electric utility legal action, we demonstrate that utilities based in states with more pro-climate state-level policies were less likely to oppose the CPP, and more likely to support it. This relationship holds even accounting for state-level political variables and utility attributes. In our second quantitative analysis, we broaden our scope to examine the participation of utilities in ad hoc coalitions either supporting or opposing national-level climate policy. We again find an association between state policy environments and coalition membership, with utilities based in states with more pro-climate policies more likely to belong to pro-climate coalitions. Yet, in this case, the evidence suggests this relationship is driven more so by underlying political variables - suggesting a logic of cost avoidance through strategic alignment-than by cost absorption from prior state policy adoption. We complement our quantitative analysis with qualitative interviews to identify causal mechanisms through which state policy and politics shape firm preferences. Interviews with elite actors indicate that both cost absorption and cost avoidance have played a role in utility position-taking.

Our argument on a home state effect speaks to recent work on the role of organized interests in mediating interdependencies across sites and levels of government in American federalism. This work has shown that sub-national governments engage in national politics (Goldstein and You 2017; Darmofal et al. 2019; Payson 2020; Karch and Rose 2019), and that policies adopted in one state can affect the ability of interest groups to engage politically in other states (Darmofal et al. 2019; Finger and Hartney 2019; Trachtman 2020b). We extend this line of research by highlighting the ways sub-national governments can also influence business preferences in the national politics. In doing so, we build on "California effect"-type dynamics, whereby product standards diffuse upward due to the lobbying of businesses that prefer a single national standard to policy patchworks (Vogel 1995). We broaden this early notion in two ways. First, the mechanisms underpinning the California effect are particular to product standards, a subset of policy instruments. And the upward diffusion advocated by firms depends on trade. We suggest that a much broader set of sub-national policies can shift firm preferences through the mechanism of cost absorption. This mechanism applies to both trade-exposed and non-tradeexposed sectors. Second, we propose that state politics - in addition to state policy-can shape the national-level positions of firms seeking to avoid regulatory cost by strategically aligning with state governments.

These interdependencies are essential in climate politics. The scope of the problem requires national-level policy, but progress has been much more attainable at the sub-national level (Rabe 2004). The political power of incumbent interests remains an impediment to national (and sub- 
national) reforms (Skocpol 2013). At the same time, our research identifies the origins of change in the composition of national climate coalitions. While the opposing coalition is broad and powerful along the fossil fuel supply chain (Cory, Lerner, and Osgood 2020), the policies of progressive states have begun to reconfigure national climate coalitions.

This article unfolds as follows. First, we develop our argument in the context of debates on firm preferences and federalism. Second, we investigate the home state effect in U.S. climate politics. Finally, we identify avenues for future research on organized interests and federalism.

\section{Firms and Federalism}

Firms are among the most powerful organized interests in modern politics, particularly American politics, so it is crucial to understand what drives their preferences. A broad set of research has shown that a variety of economic factors-including asset portfolios, trade exposure, and industrial organization-affect firm preferences in areas such as trade policy and environmental policy (Falkner 2008; I.S. Kim and Osgood 2019; Milner 1999). Some scholars have demonstrated that institutional factors including policy legacies and trade association membership (Woll 2009; Martin 1995) intersect with economic interests in shaping firm preferences.

The literature on firm preferences toward climate policy specifically reflects the importance of both economic and institutional factors (Levy and Kolk 2002; Meckling 2015). Collectively, the literature has begun to develop a systematic understanding of how economic factors in particular shape climate policy preferences, with recent research highlighting the trade exposure of polluting sectors (Genovese 2019), competitive dynamics vis-a-vis other producers (Kennard 2020), and embeddedness in fossil fuel supply chains (Cory, Lerner, and Osgood 2020) as explanatory variables. A systematic understanding of the effect of institutions on climate policy preferences, however, remains elusive. In this article, we aim to begin to address this question by focusing on a central feature of firms' institutional environments: federalism.

In federal systems such as the United States (U.S.), the co-existence of policies at both the national and sub-national level can create complementary or conflicting pressures for firms. In climate politics specifically, sub-national entities such as states and provinces have often been policy leaders compared to national governments, particularly in the Anglo-Saxon developed world. Yet, the relationship between federalism and how organized interests engage in politics remains an underexplored area of study in American and comparative politics. Research on federalism has predominantly examined inter-governmental dynamics and policy adoption, focusing on vertical (state-federal) and horizontal (state-state) interactions (Volden 2002, 2005; Oates 1999; Hooghe 2001). This focus on policymakers and policy adoption comes at the cost of understanding the broader political effects of sub-national policies and politics. This includes in particular cross-level effects on organized interests which are central to modern political life. 
Some recent research has begun to pay greater attention to these effects, in particular with regard to unions and city governments (Goldstein and You 2017; Darmofal et al. 2019). In the following, we focus on firms, whose political clout is significant in policy-making. We advance arguments about the effects of, first, state policy, and second, state politics on national firm preferences.

\subsection{State Policy and Firm Preferences}

Does economic competition between firms lead to a regulatory race to the top or to the bottom (Volden 2002; Vogel 1995)? Most existing scholarship on federalism and policy diffusion takes this as the guiding question and examines the influence of firms on policy in this context (Shipan and Volden 2008; Gilardi 2010).

David Vogel's seminal "Trading Up" (1995) demonstrated a race to the top in U.S. auto emissions standards. After California adopted more stringent regulation than the rest of the U.S., automakers asked the federal government to adopt uniform standards that would preempt state-level standards (Vogel 1995). These ideas have since inspired work in international political economy on the race to the top versus the race to the bottom in environmental regulation (Prakash and Potoski 2006). ${ }^{1}$ In this strand of research, trade is the central mechanism driving multi-level interactions and political change.

Trade can mobilize firms in a number of ways. First, firms may lobby for the adoption of harmonized product standards at a higher-level jurisdiction to limit transaction costs of regulatory fragmentation. This is the story of auto emissions standards (Vogel 1995). Second, firms can seek to export compliance cost to competitors outside their home jurisdiction by lobbying for the adoption of their home-state regulation at a national or international level. For instance, the U.S. fishing industry lobbied for the negotiation of an international treaty to level compliance cost with foreign competitors (DeSombre 2000). Theoretically, the same could hold for the interplay of sub-national and national policy. Third, firms may lobby other jurisdictions to adopt similar policies to their home state if these offer benefits to the firms and allow for market expansion. For instance, installers of solar photovoltaics that emerged in U.S. states with early support policies lobbied other states to adopt similar policies to expand their market (Trachtman 2020b; Stokes 2020).

Here, we argue that the home state effect on firm preferences extends to sectors not exposed to trade, and beyond product standards to a broader set of regulations. Firms operate in environments with overlapping policies at different political levels. These policies are often adopted at different points in time. The policy that comes first can affect firm preferences through mechanisms related to cost absorption. Cost absorption means that firms' current or expected cost structure changes as they comply with sub-national policy. This in turn affects their preference for costly national policy-resulting in either a neutral or supportive position. To the extent that firm preferences matter for national policy decisions, this process can result to an upward diffusion of sub-national policy by reducing political opposition and/or increasing

\footnotetext{
${ }^{1}$ Research in international political economy and international business has examined the effects of home vs host countries on the market and political strategies of multinational firms (Rugman and Verbeke 1998; Noorderhaven and Harzing 2003).
} 
political support. ${ }^{2}$ Cost absorption can change firm preferences in a number of ways, including through asset changes, regulatory relief, and future expectations.

First, compliance with sub-national policy can require firms to make capital expenditures. In our case of electric utilities and climate policy, this relates in particular to renewable energy and energy efficiency investments. If the investments shift the composition of asset portfolios substantially toward lower-carbon assets, firms may be incentivized to support national policies. Utilities compelled by sub-national policies to shift to lower-carbon assets are less likely to incur costs from potential national policies, and therefore less likely to oppose them. Moreover, in cases where federal policies like renewable energy subsidies enhance the profitability of the new assets, or where public support for regulations offers reputational or political benefits, firms may be more likely to support them (Meckling 2015).

Second, firms exposed to costly sub-national regulation may seek regulatory relief from a national policy that supersedes sub-national policy. National policy-making may lead to lowestcommon-denominator policies compared to, for example, liberal U.S. states that tend to champion stringent regulations. Thus, firms in states with more costly policy than the national policy proposal may support the national policy. While the resulting national policy may be less stringent than the sub-national policy, its national scope could increase overall environmental benefits.

Third, firms may interpret sub-national policy-making to have political momentum toward a more regulated future. If firms operate on long capital cycles as is particularly the case in the energy industry, they may seek regulatory clarity at the national level to reduce uncertainty for long-term investments (Fabrizio 2013). For example, the development of several state-level carbon pricing systems may indicate growing momentum toward national carbon pricing. This may incentivize utilities to support national carbon pricing to gain clarity about the design of a national system. This would reduce the policy uncertainty for long-term asset investments. This mechanism is thus about the expectations of future regulatory costs/benefits.

\subsection{State Politics and Firm Preferences}

In addition to state policy, state politics can also affect firm preferences in national politics. As much as firms are embedded in multi-level systems of policies, they are also embedded in multi-level systems of politics. In many cases, state governments take positions with respect to federal policies. Firms may align with those positions to gain or maintain political capital, and thus access to state-level policymakers that could help them shape future regulation.

Political capital, here understood as "a firm asset consisting of relationships and ties with political and regulatory players" (J.H. Kim 2019, 1913), is important to firm performance (Faccio 2006). Firms' political capital depends on multiple factors including policy expertise, whether it

\footnotetext{
2 This assumes that firms comply with sub-national policy. Often, the first step is to push back against costly policy, but if this battle is lost or deemed too expensive, then firms begin to absorb regulatory cost (You 2017).
} 
is foreign or domestic, and also preference similarity between a firm and governments. We focus on this third factor, preference similarity, which is essential to information exchange and political access (Carpenter, Esterling, and Lazer 2004). Policymakers often hold their own preferences and will grant access to interest groups that support their agenda (Woll 2007). Firms, in turn, may align with policymakers in order to invest in political capital and potentially improve their capacity to influence future policies.

The mechanism through which state politics thus shapes national firm preferences is cost avoidance-by building and maintain political capital, firms seek to avoid future regulatory cost. Cost avoidance operates through the path of strategic alignment. In the context of federalism, the logic of strategic alignment suggests that a firm might support national policy reform, even in the absence of prior state policy reform, if its home-state government supports national policy change. These dynamics are particularly important in areas like energy in which state governments play a strong regulatory function. In these areas, sub-national governments, in addition to lobbying higher levels directly, might be represented by proxy through the strategically aligned positions of the firms they regulate.

How state politics shapes national firm preferences through the mechanism of cost avoidance contrasts with how, we have argued, state policy can influence firm preferences through mechanisms associated with cost absorption. Political and policy mechanisms of firm preference change can thus be understood to operate at different stages of the policy cycle. Political mechanisms can take effect prior to state-level policy adoption as firms seek cost avoidance. Policy-related mechanisms, on the other hand, take effect after firms absorb costs from policy adoption. ${ }^{3}$

Firms may operate in multiple states, and thus be subject to multiple home state effects. ${ }^{4}$ These states may have diverging policies and politics creating cross-cutting pressures on firms. Firms thus need to reconcile potentially conflicting home state effects internally in developing an aggregate preference on federal policy. We assume that firms will weight different home state

\footnotetext{
${ }^{3}$ The mechanisms of strategic alignment and cost absorption also lead to different types of preference shifts. The literature on firm preferences has, for example, differentiated between 'genuine' and 'strategic' preferences (Hacker and Pierson 2002). State policy-related asset changes would lead to genuine preference change, meaning they would shift the underlying economic interest of firms. Whereas strategic alignment with state policymaker preferences is a strategic move that does not alter the underlying economic interest.

${ }^{4}$ The role of multiple institutional pressures-both convergent and conflicting-in shaping firms' market and nonmarket strategies are widely acknowledged in the study of international business (Rosenzweig and Singh 1991). This literature largely points to firms adopting multiple political strategies for different markets in which they operate (Baron 1997). Few studies examine how conflicting pressures shape the formation of international policy preferences, a case in which internal aggregation of multiple preferences resulting from different home country effects is required.
} 
effects in formulating an aggregate preference depending on their level of exposure to different state policies and politics.

\section{Investigating the Home State Effect on National Policy Preferences}

Here, we examine the home state effect in U.S. climate policy-making. We first introduce the broad policy area and provide some historical context for our empirical investigation. We then quantitatively investigate the home state effect on electric utilities in the cases of the CPP and ad hoc coalition membership. Finally, we leverage interview evidence to shed light on the causal mechanisms by which state-level factors shape firm preferences on national policy.

\subsection{U.S. Climate Politics}

Multi-level political and policy change have characterized U.S. climate policy-making for the last thirty years (Rabe 2018). This resulted in a pattern of "iterative federalism," in which regulatory lacuna at the federal level led to state-level policy development, followed by periods of federal policy efforts (Carlson 2009). This has led to four distinct periods of U.S. climate policy development.

First, the Clinton administration showed some leadership on climate policy, adopting an emissions reduction target and proposing a British thermal unit tax, which would be levied based on the heat content of the fuel. At that time, just a few U.S. states had begun to experiment with climate policy-making. Second, when the Bush administration withdrew the U.S. from the Kyoto Protocol in 2001, climate policy development centered around a small set of progressive states. Third, the Obama administration featured an increase in federal attempts to pass policies, including the American Clean Energy and Security Act of 2009 and the Clean Power Plan of 2015. Fourth, the Trump administration initiated a period of federal retrenchment in climate policy, while a set of states are expanding their climate and renewable energy policies.

The pattern of iterative federalism highlights the centrality of state-level climate and clean energy policies in the U.S. Climate policy in the states dates back to the 1990s, with the number of active states growing in the 2000s. Renewable portfolio standards are the policy that has spread most widely. A deployment mandate, the policy requires utilities to provide a certain share of their electricity from renewable sources. By June 2019, 29 states and the District of Columbia had enforceable renewable portfolio standards (RPSs) or other renewable energy mandates in place. Carbon pricing systems have also been adopted in the states, though much less widely than renewable portfolio standards. In 2009, a coalition of Northeastern states created the Regional Greenhouse Gas Initiative, a cap-and-trade system for the power sector. In 2015, California launched its economy-wide cap-and-trade system.

Recent work has demonstrated growing polarization of state climate and clean energy policies (Trachtman 2020a). This reflects a broader pattern in American politics whereby state policies across a number of dimensions have become more polarized along partisan lines (Kelly 
and Witko 2012; Caughey, Warshaw, and Xu 2017; Grumbach 2018). In this article, we explore how variation in state climate policies has shaped national-level firm preferences-particularly those of electric utilities.

Thousands of electric utilities are involved in the generation, transmission, and distribution of electricity in the U.S. power grid, and electric utilities have long been major political actors in energy policy issues at the federal, state, and local levels (Stokes 2020). As an industry, electric utilities offer a hard test for the home state effect. The majority of U.S. states (33) have regulated electricity markets in which vertically-integrated utilities own and operate electricity from generation to the meter. In these markets, utilities face no out-of-state competition. In addition, they can recover cost through rate negotiations with regulators. In some deregulated markets such as California, utilities also face very little competition. Overall, utilities thus have few incentives to seek to impose the compliance cost they face under home state regulation on outof-state firms through the passage of federal policy. We would expect a stronger home state effect for industries that are subject to home state regulation and exposed to significant interstate competition.

To generate our sample for empirical analysis, we used data from the Energy Information Administration (EIA) to identify the largest 100 utilities by Mwh of electricity delivered, as well as the 100 largest utilities by Mw of generation ownership (as of 2015). ${ }^{5}$ We also identified the largest utilities by electricity delivered and generation ownership in each state. ${ }^{6}$ Our sample is the union of the top 100 utilities by electricity service, top 100 utilities by generation ownership, top utility in each state by electricity service, and top utility in each state by generation ownership. This yielded a total of 159 utilities in the sample, covering 97 percent of electricity generation capacity and 93 percent of electricity sales. We restricted the analysis to large-scale electric utilities, since we expected larger firms to be more likely to be involved in national policy issues, and their involvement to be more likely to have implications for policy decisions.

\subsection{Evidence from the Clean Power Plan}

Our first empirical analysis examines the positions taken by utilities with respect to the Clean Power Plan (CPP). ${ }^{7}$ The CPP was first proposed by the EPA under the Obama administration in

\footnotetext{
${ }^{5}$ These data are available via Forms EIA-860 and EIA-861. We adopt a broad definition of utilities, including both electric distribution companies and owners of large, centralized generation.

${ }^{6}$ We added these utilities to the sample to increase variation across the states, since the key independent variables are measured at the state level.

${ }^{7}$ As mentioned above, the American Clean Energy and Security Act of 2009 (ACESA), which passed the House but not the Senate, was the other major climate episode of the Obama presidency. ACESA, unlike the CPP, provides minimal empirical leverage to test our hypotheses. First, utility advocacy around ACESA was characterized to a much greater extent by disagreements over the design of the policy, in particular the allocation of permits, than by outright support or opposition to the law (Pooley 2010). As a result, we do not observe any utilities taking public positions of opposition and observe only 15 utilities in our sample taking positions of support. Second, at the time ACESA was
} 
July 2014 and was published in October 2015. The legal justification for the CPP is based on EPA's authority to regulate carbon dioxide as a pollutant under the Clean Air Act, as determined in Massachusetts vs. EPA. ${ }^{8}$ The rule established national $\mathrm{CO}_{2}$ emissions performance rates for existing coal and gas plants, and the EPA determined state-specific requirements for emission reductions by 2030 by applying national rates to states' generation mix in 2012 (Davis, Bollinger, and Dijkema 2016; McCarthy et al. 2017).

States were given flexibility with respect to how to achieve performance rates. By and large, states that had taken early action to transition to less carbon-intensive power generation had lower emission reduction targets under the CPP. This reflects a general pattern of policy-making: federal policies generally give states credit for early action, usually either by granting credits under a uniform federal standard or by creating state-specific standards. As a result, the regulatory costs electric utilities expected to face under the CPP were directly related to the existing policies in the states in which they operated. Utilities in states with more stringent policies had already absorbed regulatory cost, so faced lower costs under the CPP.

The CPP has been politically and legally contested since even before it was published (Tsang and Wyatt 2017). Opponents, including 26 state attorneys general, three labor unions, several non-profit policy organizations, and energy companies began filing legal petitions challenging the Rule the day it was published (Ibid.). These petitions were ultimately consolidated into one case: West Virginia v. EPA. A number of organizations, firms, and governments also intervened in West Virginia v. EPA in support of the CPP.

The key outcome we examine is participation and position of electric utilities in West Virginia v. EPA. We coded the 26 utilities in the sample that participated as petitioners against the CPP in the lawsuit as oppose, and the 13 utilities that intervened in favor of the CPP as support. The remaining 120 utilities in the sample were coded as no position. ${ }^{9}$ Our theoretical framework suggests that state-level policy and political landscapes might influence utilities' position-taking with respect to the CPP, with utilities operating in states with stronger (weaker) state-level

proposed early in the Obama presidency state climate policies were significantly less advanced and polarized than at the time the CPP was debated in Obama's second term.

8 In 2011, the Supreme Court upheld Massachusetts vs. EPA, and determined the rule also applied to stationary sources, including power plants (American Electric Power Co v. Connecticut).

${ }^{9}$ West Virginia v. EPA also implicated broader questions about interpretation of the Clean Air Act that went beyond the CPP. However, interviews with utility executives and managers suggested broadly that participation in the lawsuit generally reflected positions on the CPP rule itself. In addition, there was significant overlap in utilities' positions on West Virginia v. EPA and other public statements made by the companies on the CPP. 15 of the 26 opponent utilities (or their parent companies) also made other public comments opposing the CPP. Finally, utilities' legal intervention in support of the CPP directly referenced how the Rule would affect their business. For instance, the companies state in their joint brief: "The [Clean Power Plan] harnesses existing trends within the electricity sector, recognizing the practical realities of how the integrated electricity grid operates and how utilities are already achieving $\mathrm{CO} 2$ reductions" (Poloncarz and Ristow 2016, 1). 
climate policies - as well as in states where government officials supported (opposed) the CPPmore likely to support (oppose) the CPP. ${ }^{10}$

Our measurement of state-level policy relies on measures of policy stringency along four policy dimensions: RPSs, cap and trade, energy efficiency, and distributed solar. While we do not suggest that these policies provide a complete picture of utility-related state climate and clean energy policies, we believe that, put together, they can provide an informative measure of a state's overall policy environment. In this vein, rather than include separate variables measuring regulatory stringency on each policy dimension, we scale the policies to one utility clean energy policy score in order to explore how utilities respond broadly to their policy environmentsversus any one specific policy.

We use principal component analysis to generate the utility clean energy policy score. The first principal component explains 64 percent of total variation in the four policy variables. ${ }^{11}$ In addition, as demonstrated in the Appendix (A.1), measures of policy strength in each policy area (for instance, stricter RPS requirements, greater energy efficiency expenditures, etc.) load positively onto the first principal component, suggesting it can be interpreted to represent the stringency of state policy environments. Appendix Figure A1 demonstrates that, as expected, liberal-leaning states in the West and Northeast score high, while conservative-leaning states in the South, Midwest, and Mountain West score low.

Measuring state-level political environments is more straightforward. In this case, we are able to measure the positions of state governments directly by recording whether state attorneys general participated in West Virginia v. EPA either in support or opposition to the CPP. We measure state participation on a scale from -1 to 1 , with -1 representing opposition, 0 nonparticipation, and 1 support for the CPP. Overall, 27 states challenged the CPP and 18 states supported it. In addition, we measure the political lean of a state's electorate by recording Democratic vote share in the 2016 Presidential election.

Our outcome is at the utility level, but key explanatory variables are measured at the state level. A complication in matching state-level variables to utilities is that many utilities in the sample provided electric service or owned generation in multiple states. For these utilities, we generated state-level variables by calculating weighted averages of electricity service and

\footnotetext{
${ }^{10}$ One potential concern is that utilities with underlying pro-climate corporate culture select into states with more stringent climate and energy regulations. However, the great majority of utilities in our sample have maintained a long-standing presence in the states in which they operate. And, historically, electric utilities held mostly uniform positions of opposition to climate policy. The variation across the sector is a relatively recent phenomenon. As one example, PG\&E, now one of the most pro-climate policy utilities, was a founding member of the anti-climate policy (and now defunct) Global Climate Coalition in 1989. In the cases where utilities expand, investments generally occur in the same regions as legacy assets.

${ }^{11}$ Other principal components have eigenvalues less than 1, so we do not interpret them.
} 
generation assets across states. ${ }^{12}$ This follows our theoretical rationale of preference aggregation discussed above.

In addition to state-level policy and political variables, our analysis includes covariates at the utility level. Prior research suggests that the composition of utility resource portfoliosparticularly coal assets-influence policy preferences (Downie 2017). We therefore include measures of coal assets and non-carbon assets (e.g., nuclear, geothermal, wind, solar) in our analysis. Accounting for resource portfolios also likely captures a significant portion of the variation in the carbon intensity of utilities' supply chains, which has been shown to shape firm preferences for climate policy (Cory, Lerner, and Osgood 2020). We also adjust by variables measuring utilities' size, both in terms of ownership of generation capacity as well as retail electric sales. Finally, we account for utility corporate governance with an indicator variable representing whether utilities are publicly owned. In certain models we also adjust by state-level covariates. These include state GDP per capita, tax revenue per capita, wind energy potential, air quality, unemployment rate, and electricity prices. Summary statistics for each variable included in models are provided in Appendix Table A2.

We use ordinal logistic regression to examine the factors shaping whether utilities opposed the CPP directly or through coalition membership (coded as -1), did not participate in legal action (coded as 0 ), or supported the CPP as intervenors (coded as 1 ). Regression results for the main variables of interest are presented in Table 1, with the full set of coefficient estimates provided in the Appendix (A.5). Column (1) demonstrates a strong descriptive relationship between state policy and utility positions on the CPP. Below the median state policy score, 27 percent of utilities opposed the CPP in court, and just 4 percent of utilities supported the CPP. Above the median, just 6 percent of utilities opposed and 13 percent supported the CPP.

Column (2) adds the state-level political variables (Democratic presidential vote share and state government position) discussed above. While these variables are highly correlated, it is notable that the coefficient on each is positive. Policy score, state government positions, and partisan lean in the electorate are all associated with greater support, and lower opposition to the CPP. But the only statistically significant variable in this model is state policy score. Column (3) adds the utility-level variables discussed above. Even adjusting for utility generation assets, we find again that state policy score is statistically significantly associated with CPP positions. The coefficient of 4.11 suggests that a .1 point difference in a state's utility clean energy policy score $(S D=.26,0-1$ scale) is associated with a 51 percent increase in the likelihood of a utility based in that state supporting the CPP (compared to non-participation). This result holds conditional on state-level covariates as well, as demonstrated by column (4).

${ }^{12}$ See Appendix (A.2) for details. 
Table 1: The effects of state policy and politics on CPP litigation

\begin{tabular}{lcccc}
\hline & \multicolumn{4}{c}{ CPP litigation position } \\
& $(1)$ & $(2)$ & $(3)$ & $(4)$ \\
\hline State policy score & $4.01^{* * *}$ & $2.55^{*}$ & $4.11^{* * *}$ & $4.48^{* *}$ \\
& $(0.98)$ & $(1.43)$ & $(1.71)$ & $(2.12)$ \\
Democratic 2016 presidential vote & & 0.65 & -0.55 & -2.38 \\
& & $(3.40)$ & $(3.48)$ & $(4.35)$ \\
State government position & & 0.62 & 0.40 & 0.36 \\
& & $(0.38)$ & $(0.44)$ & $(0.41)$ \\
Utility-level covariates & & & $\checkmark$ & $\checkmark$ \\
State-level covariates & 159 & 159 & 159 & 159 \\
\hline Observations & & & & \\
\hline \hline
\end{tabular}

Coefficients from ordinal logistic regression model with three levels: oppose, no action, and support. Robust standard errors clustered at parent company level. ${ }^{*} \mathrm{p}<.1 * * \mathrm{p}<.05 * * * \mathrm{p}<.01$.

It is worth taking a closer look at the utilities that intervened in support of the CPP, since they are a significant minority, but also represent the potential emergence of a pro-clean energy coalition of electric utilities. As indicated by Appendix Table A3, the pro-CPP coalition represents both utilities servicing Democratic strongholds with strong state-level climate policies and goals (e.g., PG\&E), as well as utilities with significant generation ownership focused on growing their clean energy portfolios (e.g., NextEra). Moreover, this coalition appears to be relatively robust. Many of the utilities that supported the CPP have also petitioned the D.C. Circuit of Appeals challenging the Trump administration's decision to replace the CPP with the much weaker Affordable Clean Energy rule (ACE) (Walton 2019).

One potential concern with the prior analysis is the high number of utilities not participating in litigation. The reasons for the high number of firms with no position may be twofold. First, litigation is costly action that firms weigh carefully against the potential benefits. Second, our theoretical expectation suggests that a home state effect reduces the opposition to national policy, which can result in either a neutral or supportive national preference. Our test of litigation in favor of the CPP thus is a hard test of the home state effect that leads to national policy support.

\subsection{Evidence from Ad Hoc Coalitions}

In this section, we turn our attention to a broader outcome than utilities' positions on a specific policy: utilities' membership in ad-hoc coalitions either supporting or opposing federal efforts to mitigate climate change.

Our analysis relies on data assembled by (Cory, Lerner, and Osgood 2020), which we will refer to as the ad hoc coalitions data. Cory, Lerner et al. assemble an exhaustive list of the coalitions that have organized to engage in 'outside' lobbying (Kollman 1998) on climate change 
from 2000 to 2019 in the U.S., and code the positions taken by these coalitions according to their public statements. The formation and maintenance of ad hoc coalitions is one of the standard ways that firms engage in environmental and climate politics in the U.S. Importantly for our usage of these data, Cory, Lerner et al. also record firm membership in these climate coalitions based on lists available on the coalitions' websites.

Bringing these rich and newly disseminated data together with the data we assembled on utility assets and state policies allows us to examine the home state effect in this second empirical context. We leverage the same sample of 159 large electric utilities as in the prior analysis for consistency and take 2015 as our base year (excluding coalitions that were not active as of 2015). Coalitions that were only active at the state or regional level were also excluded. Of national coalitions active in 2015, 17 featured electric utilities as members (Appendix Table A4). We use electric utilities' membership in these ad hoc coalitions as our outcome here.

As a broad measure of utilities' positions with respect to ad hoc coalitions, we code utilities that were only members of opposing coalitions as opposed (35 utilities), and utilities that were only members of supportive coalitions as supportive (25 utilities). Again, we use ordinal logistic regression to estimate the association between state-level factors and utilities' membership in pro- and anti-climate ad hoc coalitions, with outcomes as -1 for oppose, 1 for support, and 0 for utilities that were either members of both opposing and supportive groups (which characterized 23 utilities), or no coalitions (78 utilities). ${ }^{13}$

Regression results for the main variables are presented in Table 2, with full results including covariates provided in the Appendix (A.5). Column (1) displays a (non-statistically significant) association between state policy scores and pro-climate coalition membership. Yet, when we add political variables measuring broad political lean (2016 Democratic vote share) and control of state government, results suggest that political lean is the strongest predictor. (We suspect the negative coefficient on state policy score in this model is spurious, reflecting unstable estimates generated by the high correlation between measures of state policy and measures of state politics (Allen 1997).) This result holds accounting for utility-level variables as well, as demonstrated by Column (3). The coefficient of 8.12 suggests that a 10 -point shift in Democratic vote share is associated with utilities being 2.25 times more likely to belong to supportive coalitions (versus no coalitions). ${ }^{14}$ We recover similar results in the model adjusting for statelevel covariates, with results presented in column (4).

\footnotetext{
${ }^{13}$ We recognize that non-membership and membership in both supportive and opposing coalitions could signify different preferences. Results are robust to excluding utilities that were member to both opposing and supportive groups. See Appendix (A.4).

${ }^{14}$ Results are robust to a specification where the outcome is measured as the number of pro-climate coalitions a utility is member to minus the number of anti-climate coalitions a utility is member to. See Appendix (A.4).
} 
Table 2: The effects of state policy and politics on climate ad hoc coalition membership

\begin{tabular}{lcccc}
\hline & \multicolumn{3}{c}{ Ad hoc coalition position } \\
& $(1)$ & $(2)$ & $(3)$ & $(4)$ \\
\hline Policy score & 1.24 & $-2.01^{*}$ & -1.54 & -1.59 \\
Democratic 2016 presidential vote & $(0.77)$ & $(1.02)$ & $(1.17)$ & $(1.46)$ \\
& & $10.12^{* * *}$ & $8.12^{* * *}$ & $10.40^{* * *}$ \\
Control of state government & $(3.19)$ & $(3.23)$ & $(4.09)$ \\
Utility-level covariates & 0.33 & 0.17 & -0.05 \\
State-level covariates & $(0.41)$ & $(0.42)$ & $(0.43)$ \\
Observations & & $\checkmark$ & $\checkmark$ \\
\hline \hline
\end{tabular}

Coefficients from ordinal logistic regression model with three levels: oppose, neutral, and support. Robust standard errors clustered at parent company level. ${ }^{*} \mathrm{p}<.1 * * \mathrm{p}<.05 * * * \mathrm{p}<.01$.

Broadly speaking, the analysis of utility participation in ad hoc coalitions supports our main descriptive findings from the CPP analysis. But an important difference in this analysis is the role of state politics, as opposed to state policy. Studying the CPP, we find that measures of state climate policy stringency are most strongly associated with participation in litigation supporting (and not opposing) the rule. But studying utility membership in ad hoc climate coalitions, we find that a broader measure of the state political environment (e.g., Democratic vote share) is the strongest predictor of membership in pro-climate policy coalitions (and non-membership in opposing coalitions).

We believe that these differences reflect variation in specific attributes of the outcome variables: CPP litigation and ad hoc coalition membership. In determining how to respond to the CPP, electric utilities had a good idea of the specific requirements and compliance costs that the policy would impose. Policy uncertainty was low. Indeed, a number of electric utilities based in states with stringent climate policies successfully lobbied to ensure that their efforts to comply with state policies (e.g., renewable portfolio standards) also satisfied CPP requirements. ${ }^{15}$ Our finding that state policy measures are associated with utilities' participation in litigation challenging the CPP is consistent with the direct and visible link between state policy environments and utilities' new obligations under the CPP.

The ad hoc coalitions outcome provides, on the other hand, a measure of utilities' more general positions vis-à-vis potential federal climate policies. The compliance costs (or benefits) of these potential federal regulations are more variable than in the case of the CPP. We think that this variability might strengthen the role of states' political environment versus policy

\footnotetext{
${ }^{15}$ Interview with regulatory policy manager at large electric utility based in a liberal state, 10/12/2020.
} 
environment for two reasons. First, under conditions of high policy uncertainty, utilities might respond to the variability of potential compliance costs from future regulations by drawing on their political environments as a rough heuristic for the policy environment they might be face in the future. Second, the variability of potential compliance costs might compel utilities to upweight other factors like strategic alignment. Taken together, the results suggest that a state policy effect may be more likely under low policy uncertainty, whereas the state politics effect may be stronger under high policy uncertainty.

\subsection{Evidence from Elite Interviews}

Overall, the quantitative evidence provides broad support for the general perspective we put forth in this paper: the positions electric utilities take on national-level policy issues are associated with the state-level policy and political environments in which they operate, even once we account for key economic variables like resource portfolios. Yet, the quantitative design provides limited leverage for parsing mechanisms. While we are able to distinguish to some extent between state politics and state policy, our precision is somewhat limited since these tend to be highly correlated.

To bolster the quantitative analysis and more deeply explore mechanisms, we conducted 11 semi-structured elite interviews with individuals working on public policy in or close to the electric utility sector. ${ }^{16}$ Six of the interviewees were individuals with manager-level and executive-level policy positions at large electric utilities in states with stringent climate policies (two of the utilities represented also held assets in states with less stringent climate policies). ${ }^{17}$ Three additional interviews were conducted with attorneys and lobbyists representing national coalitions of electric utilities. Finally, we conducted one interview with a manager at a professionalized climate advocacy organization who works closely with electric utilities, and one interview with a Department of Energy manager during the Obama administration now consulting in energy policy.

The interviews confirmed our basic hypothesis that increased state-level climate and clean energy policy-making since the mid-2000s has driven a divergence in the positions of electric utilities - with utilities based in liberal-leaning states generally more favorable towards national regulations. In addition, each interviewee pointed to both state policy and state politics driving

\footnotetext{
${ }^{16}$ We received informed consent from each of our interviewees. At the outset of each interview, we established how the interviews would be used in our research, and also established guidelines for confidentiality. Interviewees were asked what level of attribution they preferred. They generally opted for attribution by general role and type of organization. Such interviews are deemed not human subjects research by the [university name redacted] IRB since the focus is not on characteristics of the individuals, but rather on political dynamics on which the individuals have expertise.

${ }^{17}$ We focused on understanding mechanisms driving the support for federal climate policies from utilities based in liberal-leaning states, since the opposition of utilities elsewhere follows directly from models of the economic costs of new federal policies.
} 
the preferences and positions of electric utilities. But the interviews provided crucial insight into how and why state policy and politics drove utilities' positions.

In terms of state policy, interviewees were largely in agreement that resource portfolios were fundamental. Utilities operating in states with more stringent climate policies are compelled to adopt cleaner portfolios, reducing the additional obligations of federal policy. Yet, several interviewees emphasized that this effect was likely driven to a greater extent by expectations of future shifts to resource portfolios than by current portfolios. Quite simply, one said, "utilities in states with ambitious policies were ok with it [the CPP] mostly because they didn't have to do anything beyond what they were already planning to do." 18 Another stressed that their company determined its policy positions by evaluating the degree to which potential policies aligned with current investment strategies, which in turn reflected the state policy environments in which it operated. ${ }^{19}$ The role of expectations explains the association between state policy and utility positions even conditional on resource portfolio measures.

On the other hand, several interviewees disagreed with the notion that utilities operating in states with stringent policies sought regulatory relief from national regulations that would preempt state laws. They maintained that utilities generally expect any new federal regulations to be designed as floors (allowing states to adopt more aggressive regulations), not ceilings. Other interviewees, though, did suggest that utilities owning and operating assets in multiple states with multiple sets of policies have supported federal policies in order to provide a more consistent regulatory landscape.

Interviewees also raised two additional mechanisms related to how federal policy structures the costs (and benefits) of compliance with state mandates. First, for utilities operating in states with carbon trading schemes, federal carbon pricing policy would expand the permit market and give rise to new trading partners. Second, federal policy might lead to technical innovation (e.g., the development of more efficient batteries) that further reduces the costs of complying with strict state policies.

In terms of state politics, interviewees generally agreed with the notion that cost avoidance and strategic alignment factored into utilities' positions. One emphasized that this effect is particularly prominent in the case of electric utilities, which are much more heavily regulated at the state level than federal level-so maintaining a good relationship with state regulators is a major priority. The logic of strategic alignment, one interviewee speculated, explains why several utilities operating in states with stringent climate policies went further than not opposing the CPP, and actively supported it.

Several interviewees proposed that, while strategic alignment is relevant to both utilities with significant regulated assets and utilities operating mainly as independent power producers, maintaining a good relationship with state regulators is more important to utilities with a greater

\footnotetext{
18 Interview with former Department of Energy official, 8/31/2020.

19 Interview with regulatory policy executive at large investor-owned utility, 12/21/2020.
} 
proportion of regulated assets. State regulators, for these utilities, directly determine profits through their decisions in utilities' rate cases. One interviewee who worked at a utility with assets in both liberal-leaning and conservative-leaning states even suggested that trying to satisfy regulators in both sets of states posed issues for executives determining what positions to take on federal policies.

Finally, we should note that several interviewees suggested that the divergence in utility positions based on state-level policy and political factors has likely shrunk in recent years (since 2015). They pointed to two key reasons. First, as the effects of climate change have become clearer and more salient in the public, utilities operating in states across the country increasingly recognize that they will have to face greater regulations. As a result, some utilities that would have previously vigorously opposed have softened their positions. Second, the reductions in the costs of solar and wind energy have acted as an equalizer. As the costs of transitioning to clean energy decline, the state policy landscapes in which utilities operate matter less in determining planning. Indeed, utilities are increasingly setting their own targets for clean energy and carbon emissions reductions, and not only in liberal-leaning areas of the country with stringent state policies. ${ }^{20}$ Of course, cost reductions have been driven by economies of scale generated in part by prior state-level deployment policy. This suggests (technology) cost reductions as a separate mechanism by which states can more broadly shift national group coalitions.

\section{Conclusion}

We have argued that firms' national policy positions can be influenced by the sub-national policy and political environments in which they operate: a home state effect. State policies force firms to shift their investments and operations in a way that affects how they view subsequent federal policy initiatives. And considerations of state-level political factors incentivize firms to align positions with their state regulators.

Our empirical analysis of electric utility preferences and coalition membership in U.S. climate policy-making supports the notion of a home state effect. Electric utilities operating in states with more aggressive climate policies were more likely to support the CPP in court, while utilities operating in more lax policy environments were more likely to oppose it. This relationship holds conditional on covariates including resource portfolios and measures of state political environments, suggesting cost absorption from prior state policy decisions was the key mechanism. We find a similar descriptive association when we investigate ad hoc climate coalition membership, with utilities operating in more liberal states more likely to belong to proclimate coalitions (and vice versa for utilities operating in more conservative states). Here,

\footnotetext{
20 For instance, Ameren Missouri has pledged to reach net-zero carbon emissions by 2050. At the same time, some recent analyses have highlighted discrepancies between utilities' voluntary targets and their investments (Romankiewicz, Bottorff, and Stokes 2020).
} 
though, the strongest driver appears to be measures of state political environment, highlighting the mechanism of cost avoidance through strategic alignment.

Future research may focus on identifying the scope conditions for different mechanisms underpinning the home state effect. First, different types of policies may well affect national policy preferences through different mechanisms, such as asset changes, regulatory relief, and future expectations. For instance, renewable portfolio standards may shift preferences through asset changes. Carbon pricing regimes, which tend to incentivize low initial capital expenditures, may operate through mechanisms of regulatory relief or future expectations. In one case asset changes operate through asset creation, in the other through asset revaluation (renewables portfolio standards promote development of clean energy infrastructure, while carbon pricing reduces the value of existing fossil fuel infrastructure). Identifying 'policy-mechanism' connections will lead to a clearer understanding of the coalitional effects of specific policy levers at the disposal of state policymakers.

Second, the nature of industries is likely to condition the relevance of different mechanisms and the strength of the home state effect. Industries vary, for example, in their capital intensity. Electric utilities tend to be on one end of spectrum, exhibiting both high capital expenditures and long capital lifecycles. Power plants and grid infrastructure stick around for decades. Under these conditions, state policy may create stickier changes in national policy preferences and more stable coalitions relative to industries with lower capital expenditures and shorter capital lifecycles. By contrast, healthcare providers participating, for example, in new pricing models under state policy may have more moderate and medium-term capital expenditures to comply with state policy. This still suggests the possibility of a home state effect, but likely less pronounced than in the case of electric utilities.

In addition, the level of inter-state competition in an industry may condition the home state effect. The more competition a firm faces from competitors in other states, the more sensitive it will be to compliance cost under home state policy. As a result, the national preferences of firms in competitive industries are likely to be shaped to a greater degree by state policies than in less competitive industries-enhancing the strength of the home state effect. In this regard, electric utilities present a hard test for the home state effect given the lack of nation-wide competition in power markets. In manufacturing industries, instead, we would expect a stronger home state effect, given both a high level of regulation at the state level, in particular labor regulation, and higher inter-state competition.

Evidence of a home state effect on national firm preferences and coalition membership has important theoretical and empirical implications. Theoretically, this article contributes to a growing body of work exploring interest group mobilization across the U.S. federal system. Recent work has demonstrated the horizontal mobilization of organized interests, as sub-national policies shape the capacities of groups to influence policy in other federal units (Darmofal et al. 2019; Finger and Hartney 2019; Trachtman 2020b). Related research has explored the vertical 
mobilization of city governments that lobby directly in national and state politics (Goldstein and You 2017; Darmofal et al. 2019; Payson 2020). This paper extends our understanding of the vertical mobilization of interest groups by specifying mechanisms by which state policy and politics can influence the preferences of business interests at the national level. It thus sheds light on how sub-national governments, next to direct lobbying, transmit their preferences into national politics.

Empirically, our research identifies the origins of change in the composition of national climate coalitions. The business coalition opposing national climate policy is broad and powerful along the fossil fuel supply chain-it conducts sixty-six percent of U.S. lobbying on climate policy (Cory, Lerner, and Osgood 2020). Yet this coalition is fraying as economic interests begin to support climate policy (Kennard 2020). State policy is a key driver and political lever. We show that state climate policy can pay broader dividends in terms of national political mobilization. Both mechanisms of horizontal and vertical mobilization offer sub-national climate leaders pathways to reconfiguring national climate coalitions. 


\section{References}

Allen, Michael Patrick. 1997. "The problem of multicollinearity." Understanding regression analysis: 176180.

Alt, James E, Fredrik Carlsen, Per Heum, and Kare Johansen. 1999. "Asset specificity and the political behavior of firms: lobbying for subsidies in Norway." International Organization: 99-116.

Baron, David P. 1997. "Integrated strategy, trade policy, and global competition." California management review 39 (2): 145-169.

Brulle, Robert J. 2018. "The climate lobby: a sectoral analysis of lobbying spending on climate change in the USA, 2000 to 2016." Climatic Change 149 (3-4): 289-303. https://doi.org/10.1007/s10584-0182241-z.

Carlson, Ann E. 2009. "Iterative Federalism and Climate Change." Northwestern University Law Review 103 (3): 1097-1161.

Carpenter, Daniel P, Kevin M Esterling, and David MJ Lazer. 2004. "Friends, brokers, and transitivity: Who informs whom in Washington politics?" The Journal of Politics 66 (1): 224-246.

Caughey, Devin, Christopher Warshaw, and Yiqing Xu. 2017. "Incremental Democracy: The Policy Effects of Partisan Control of State Government." The Journal of Politics 79 (4): 1342-1358. https://doi.org/10.1086/692669.

Cory, Jared, Michael Lerner, and lain Osgood. 2020. "Supply Chain Linkages and the Extended Carbon Coalition." American Journal of Political Science.

Darmofal, David, Nathan J Kelly, Christopher Witko, and Sarah Young. 2019. "Federalism, Government Liberalism, and Union Weakness in America." State Politics \& Policy Quarterly 19 (4): 428-450.

Davis, Chris, L Andrew Bollinger, and Gerard PJ Dijkema. 2016. "The state of the states: data-driven analysis of the US Clean Power Plan." Renewable and Sustainable Energy Reviews 60: 631-652.

DeSombre, Elizabeth R. 2000. Domestic Sources of International Environmental Policy. Industry, Environmentalists, and U.S. Power. Cambridge, MA: MIT Press.

Downie, Christian. 2017. "Fighting for King Coal's Crown: Business Actors in the US Coal and Utility Industries." Global Environmental Politics 17 (1): 21-39. https://doi.org/10.1162/GLEP_a_00388.

Fabrizio, Kira R. 2013. "The effect of regulatory uncertainty on investment: evidence from renewable energy generation." The Journal of Law, Economics, \& Organization 29 (4): 765-798.

Faccio, Mara. 2006. "Politically connected firms." American economic review 96 (1): 369-386.

Falkner, Robert. 2008. Business Power and Conflict in International Environmental Politics. Basingstoke: Palgrave Macmillan. 
Finger, Leslie K, and Michael T Hartney. 2019. "Financial Solidarity: the Future of Unions in the postJanus Era." Perspectives on Politics: 1-17.

Genovese, Federica. 2019. "Sectors, Pollution, and Trade: How Industrial Interests Shape Domestic Positions on Global Climate Agreements." International Studies Quarterly 63 (4): 819-836. https://doi.org/10.1093/isq/sqz062.

Gilardi, Fabrizio. 2010. "Who Learns from What in Policy Diffusion Processes?" American Journal of Political Science 54 (3): 650-666.

Gilens, Martin, and Benjamin I. Page. 2014. "Testing Theories of American Politics: Elites, Interest Groups, and Average Citizens." Perspectives on Politics 12 (03): 564-581. https://doi.org/10.1017/s1537592714001595.

Goldstein, Rebecca, and Hye Young You. 2017. "Cities as Lobbyists." American Journal of Political Science 61 (4): 864-876. https://doi.org/10.1111/ajps.12306.

Grumbach, Jacob M. 2018. "From Backwaters to Major Policymakers: Policy Polarization in the States, 1970-2014." Perspectives on Politics 16 (2): 416-435. https://doi.org/10.1017/s153759271700425x.

Hacker, Jacob, and Paul Pierson. 2002. "Business Power and Social Policy: Employers and the Formation of the American Welfare State." Politics \& Society 30 (2): 277-325.

Hooghe, Liesbet. 2001. Multi-Level Governanceand European Integration. London: Rowman \& Littlefield Publishers.

Karch, Andrew, and Shanna Rose. 2019. Responsive states: federalism and American public policy. Cambridge University Press.

Kelly, Nathan J., and Christopher Witko. 2012. "Federalism and American Inequality." The Journal of Politics 74 (2): 414-426. https://doi.org/10.1017/s0022381611001678.

Kennard, Amanda. 2020. "The Enemy of My Enemy: When Firms Support Climate Change Regulation." International Organization 74 (2): 187-221.

Kim, In Song, and lain Osgood. 2019. "Firms in trade and trade politics." Annual Review of Political Science 22: 399-417.

Kim, Jin Hyung. 2019. "Is your playing field unleveled? U.S. defense contracts and foreign firm lobbying." Strategic Management Journal 40 (12): 1911-1937. https://doi.org/10.1002/smj.3061.

Kim, Sung Eun, Johannes Urpelainen, and Joonseok Yang. 2015. "Electric utilities and American climate policy: lobbying by expected winners and losers." Journal of Public Policy 36 (2): 251-275. https://doi.org/10.1017/s0143814×15000033.

Kollman, Ken. 1998. Outside lobbying: Public opinion and interest group strategies. Princeton University Press. 
Layzer, Judith A. 2012. Open for Business: Conservatives' Opposition to Environmental Regulation. Cambridge, MA: The MIT Press.

Levy, David L., and Ans Kolk. 2002. "Strategic Responses to Global Climate Change. Conflicting Pressures on Multinationals in the Oil Industry." Business and Politics 4 (3): 275-300.

Martin, Cathie Jo. 1995. "Nature or nurture? Sources of firm preference for national health reform." American Political Science Review 89 (4): 898-913. https://www.cambridge.org/core/services/aopcambridgecore/content/view/FE82F53A54E528F4A7C4682370456C85/S0003055400098166a.pdf/div-classtitle-nature-or-nurture-sources-of-firm-preference-for-national-health-reform-div.pdf.

Martin, Cathie Jo, and Duane Swank. 2012. The Political Construction of Business Interests: Coordination, Growth, and Equality. New York: Cambridge University Press.

McCarthy, James E., Jonathan L. Ramseur, Jane A. Leggett, Linda Tsang, and Kate C. Shouse. 2017. EPA's Clean Power Plan for Existing Power Plants: Frequently Asked Questions. Congressional Research Service (Washington, DC).

Meckling, Jonas. 2015. "Oppose, Support, or Hedge? Distributional Effects, Regulatory Pressure, and Business Strategy in Environmental Politics." Global Environmental Politics 15 (2): 19-37.

Milner, Helen V. 1999. "The Political Economy of International Trade." Annual Review of Political Science 2 (1999): 91-114.

Noorderhaven, Niels G, and Anne-Wil Harzing. 2003. "The "country-of-origin effect" in multinational corporations: Sources, mechanisms and moderating conditions." In Management and International Review, 47-66. Springer.

Oates, Wallace E. 1999. "An Essay on Fiscal Federalism." Journal of Economic Literature XXXVII: 11201149.

Payson, Julia A. 2020. "Cities in the statehouse: How local governments use lobbyists to secure state funding." The Journal of Politics 82 (2): 403-417.

Poloncarz, Kevin, and Donald L. Ristow. 2016. Brief of Intervenors Calpin Corporation ... in Support of Respondents. In 15-1363, edited by Paul Hastings LLP: United States Court of Appeals for the District of Columbia Circuit.

Prakash, A., and Matthew Potoski. 2006. "Racing to the Bottom? Trade, Environmental Governance, and 14001." American Journal of Political Science 50 (2): 350-364.

Rabe, Barry G. 2004. Statehouse and Greenhouse. Washington, DC: Brookings Institution Press.

---. 2018. Can We Price Carbon? Cambridge, MA: MIT Press.

Romankiewicz, John, Cara Bottorff, and Leah C. Stokes. 2020. The Dirty Truth About Utility Climate Pledges. Sierra Club. 
Rosenzweig, Elizabeth, and Push Singh. 1991. "Organizational Environments and the Multiinational Enterprise." Academy of Management Review 16 (2): 340-361.

Rugman, Alan, and Alain Verbeke. 1998. "Corporate Strategy and International Environmental Policy." Journal of International Business Studies 29 (4): 819-834.

Shipan, Charles R, and Craig Volden. 2008. "The Mechanisms of Policy Diffusion." American Journal of Political Science 52 (4): 840-857.

Skocpol, Theda. 2013. Naming the Problem: What It Will Take to Counter Extremism and Engage Americans in the Fight against Global Warming. Harvard University (Cambridge, MA).

Stokes, Leah Cardamore. 2020. Short circuiting policy: Interest groups and the battle over clean energy and climate policy in the American States. Oxford University Press, USA.

Swenson, Peter A. 2018. "Misrepresented Interests: Business, Medicare, and the Making of the American Health Care State." Studies in American Political Development 32 (1): 1-23. https://doi.org/10.1017/s0898588x18000019.

Trachtman, Sam. 2020a. "What drives climate policy adoption in the U.S. states?" Energy Policy 138.

---. 2020b. Building New Power: The Effects of State-level Solar Policy on National-level Solar Politics in the U.S. Berkeley University of California.

Tsang, Linda, and Alexandra M Wyatt. 2017. Clean Power Plan: Legal Background and Pending Litigation in'West Virginia V. EPA'. Congressional Research Service Washington, DC.

Vogel, David. 1995. Trading Up. Consumer and Environmental Regulation in a Global Economy. Cambridge, MA: Harvard University Press.

Volden, Craig. 2002. "The politics of competitive federalism: A race to the bottom in welfare benefits?" American Journal of Political Science: 352-363.

---. 2005. "Intergovernmental political competition in American federalism." American Journal of Political Science 49 (2): 327-342. https://onlinelibrary.wiley.com/doi/full/10.1111/j.00925853.2005.00126.x.

Walton, R. 2019. "ConEd, 8 other utilities challenge Trump's energy rule, repeal of Clean Power Plan." UtilityDive, 2019.

Woll, Cornelia. 2007. "Leading the Dance? Power and Political Resources of Business Lobbyists." Journal of Public Policy 27 (1): 57-78. https://doi.org/10.1017/s0143814x07000633.

---. 2009. Firm Interests: How Governments Shape Business Lobbying on Global Trade. Ithaca: Cornell University Press. 


\section{Appendix}

A.1 Measuring state climate policy stringency
A.2 Applying state-level measures for utilities operating in multiple states

A.3 Summary statistics and other information

A.4 Robustness checks and alternative specifications

A.5 Full regression results 


\section{A.1 Measuring state climate policy stringency}

As discussed in the paper, we scale policy measures across four areas to generate a utility clean energy policy measure, which is a key treatment variable for the analysis of utility preferences and coalition-membership at the national level. The first dimension is renewable portfolio standards (RPS). To measure RPS, we use RPS compliance data tabulated by Lawrence Berkeley National Laboratory. Specifically, we measure RPS strength (in a given year) as a state's total RPS obligation (Mwh) as a proportion of its total electricity generation (Mwh). The second dimension of policy we include is a binary measure indicating whether a state had adopted a capand-trade program covering the power sector. The third dimension is a measure of state energy efficiency policy in the power sector. Specifically, we use data from the American Council for an Energy-Efficient Economy (ACEEE) measuring the electric savings from energy efficiency programs (Mwh) as a percentage of total statewide retail electric sales. The fourth and final dimension is a measure of state distributed electricity generation policy (mainly applicable distributed solar resource development). We use a 1-5 measure of state net energy metering (NEM) and interconnection policy produced by two pro-distributed solar advocacy organizations: VoteSolar and Interstate Renewable Energy Council.

We apply principal components analysis (PCA) to generate the state-year level utility clean energy score from these four policy measures. PCA is generally used to collapse information from a large number of variables to fewer dimensions. It is particularly useful to dimension-reduce data in cases where variables are highly correlated-which is the case for our four policies. As demonstrated by Table A1, each of the four policies loads positively onto the first principal component, suggesting that this principal component can be interpreted to measure the overall strength of a state's clean energy policies. This principal component explains 64 percent of the total variation across the policy measures. Figure A1 plots the utility clean energy scores for each state from 2015 policy measures.

Table A1: Principal component loadings

\begin{tabular}{ccccc}
\hline \hline & PC1 & PC2 & PC3 & PC4 \\
\hline RPS & 0.48 & 0.61 & -0.54 & -0.31 \\
Cap-and-trade & 0.53 & 0.30 & 0.41 & 0.68 \\
Energy efficiency & 0.52 & -0.25 & 0.54 & -0.62 \\
Distributed solar & 0.47 & -0.69 & -0.50 & 0.24 \\
\hline
\end{tabular}


Figure A1: State-level utility clean energy scores

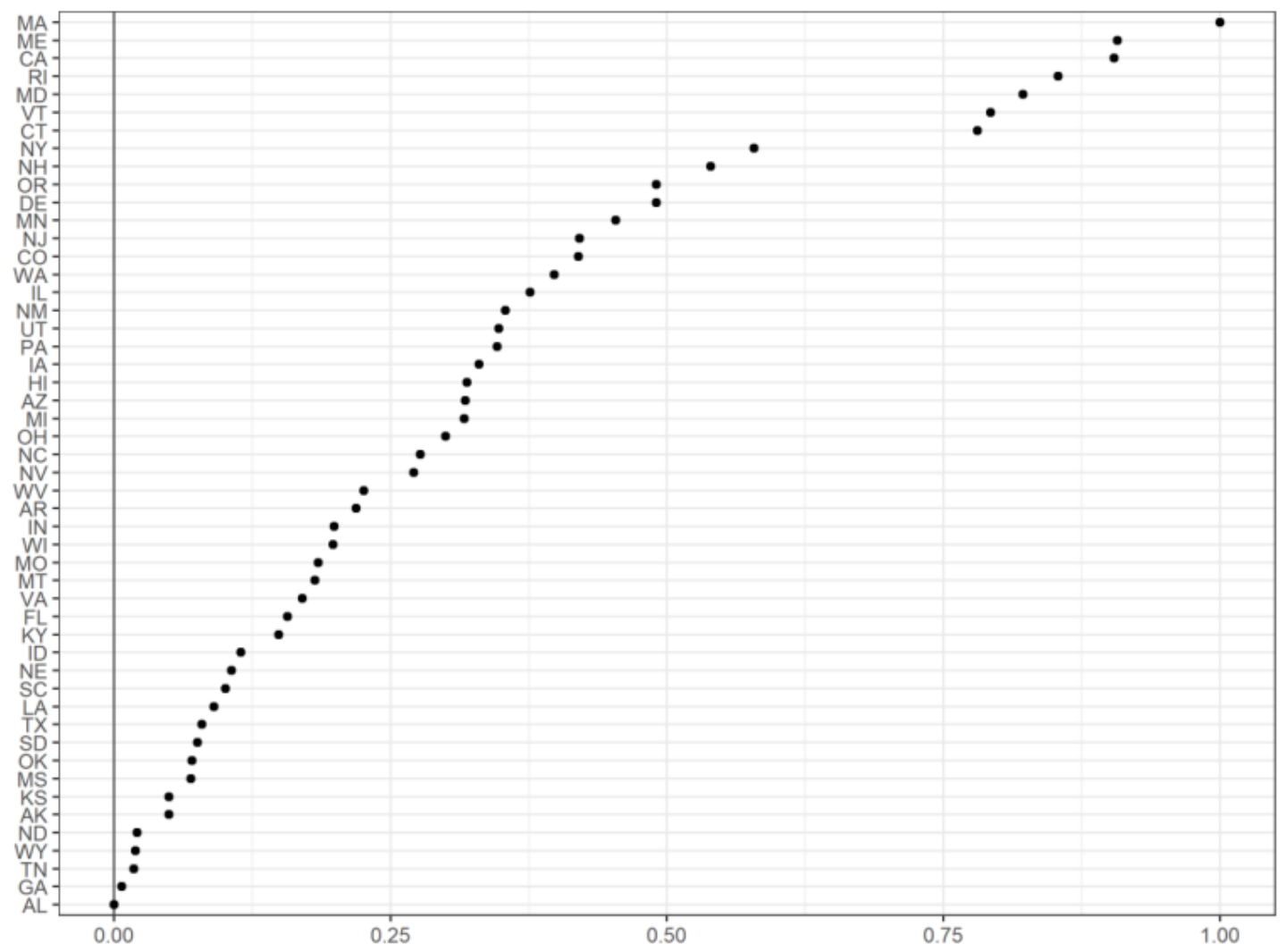

Note: Scores generated by conducting principal component analysis on policy strength measures across four policy areas: renewable portfolio standards, energy efficiency, cap-andtrade, and distributed solar. Scores represent first principal component. 
A.2 Applying state-level measures for utilities operating in multiple states

For utilities without any generation assets providing electric service in multiple states, we calculated an average of state-level variables weighted by Mwh of electricity delivered in each state. For utilities owning generators in multiple states but without direct electric service provision, we calculated an average of state-level variables weighted by Mw of capacity owned in each state. Finally, for utilities operating in multiple states with both electric service and generation assets, we calculated averages of state-level variables weighted by a combination of electric sales and generation assets-assigning greater weights to generation assets if utilities had larger generation portfolios (and vice versa for electric sales). 
A. 3 Summary statistics and other information

Table A2: Summary statistics for variables used in analysis

\begin{tabular}{lccccc}
\hline \hline Variable & Mean & St. Dev. & Min & Max & N \\
\hline Policy score & 0.31 & 0.26 & 0.00 & 1.00 & 159 \\
Democratic 2016 presidential vote & 0.45 & 0.09 & 0.26 & 0.62 & 159 \\
State government position & -0.24 & 0.85 & -1 & 1 & 161 \\
State control of government & -0.38 & 0.63 & -1.00 & 1.00 & 159 \\
Proportion coal & 0.26 & 0.29 & 0.00 & 1.00 & 161 \\
Proportion non-CO2 & 0.19 & 0.31 & 0.00 & 1.00 & 161 \\
Generation capacity (logged MW) & 6.52 & 3.39 & 0.00 & 10.50 & 161 \\
Sales (logged Mwh) & 11.16 & 7.65 & 0.00 & 18.52 & 161 \\
Public utility & 0.07 & 0.26 & 0 & 1 & 161 \\
GDP per capita (1000 USD) & 54.84 & 9.44 & 35.63 & 75.69 & 159 \\
Tax revenue per capita (1000 USD) & 2.80 & 0.76 & 1.41 & 4.94 & 159 \\
Wind potential & 8.20 & 11.95 & 0.0000 & 46.05 & 159 \\
Air quality & 37.27 & 4.79 & 20.38 & 53.50 & 159 \\
Unemployment rate & 5.18 & 0.85 & 2.70 & 6.70 & 159 \\
Electricity price (USD/million BTU) & 31.33 & 8.41 & 21.85 & 76.75 & 159 \\
\hline
\end{tabular}

Table A3: Utilities either supporting Clean Power Plan or opposing Affordable Clean Energy plan

\begin{tabular}{lll} 
Utility & Supported CPP & Opposed ACE \\
\hline Austin Energy & $\checkmark$ & \\
Calpine & $\checkmark$ & \\
Consolidated Edison & & \\
Dominion & $\checkmark$ & $\checkmark$ \\
Exelon & & $\checkmark$ \\
Los Angeles Department of Water and Power & $\checkmark$ & $\checkmark$ \\
National Grid & $\checkmark$ & $\checkmark$ \\
New York Power Authority & $\checkmark$ & \\
NextEra & $\checkmark$ & $\checkmark$ \\
Pacific Gas and Electric & $\checkmark$ & $\checkmark$ \\
Public Service Enterprise Group (PSEG) & & $\checkmark$ \\
Sacramento Municipal Utility District (SMUD) & & $\checkmark$ \\
Seattle City Light & $\checkmark$ & \\
Southern California Edison & $\checkmark$ & \\
\hline
\end{tabular}

Table A4: Ad-hoc coalitions represented in the sample 


\begin{tabular}{lc}
\hline \hline Coalition & Position \\
\hline Advanced Energy Economy & In favor \\
Advanced Energy Management Alliance & In favor \\
Alliance to Save Energy & In favor \\
American Business for Clean Energy & In favor \\
American Council for an Energy-Efficient Economy & In favor \\
American Council on Renewable Energy & In favor \\
Business Council for Sustainable Energy & In favor \\
Business Environmental Leadership Council & In favor \\
CERES & In favor \\
The Climate Group & In favor \\
We Mean Business & In favor \\
World Business Council for Sustainable Development & In favor \\
American Coalition for Clean Coal Energy & Opposed \\
Carbon Utilization Research Council (Coal Utilization Research Council) & Opposed \\
Consumer Energy Alliance & Opposed \\
Electric Reliability Coordinating Council & Opposed \\
Utility Air Regulatory Group & Opposed \\
\hline
\end{tabular}


A.4 Robustness checks and alternative specifications

Table A6: The effects of state policy and politics on climate ad hoc coalitions, specification excluding firms belonging to both supportive and opposing coalitions

\begin{tabular}{lcccc}
\hline & \multicolumn{4}{c}{ Ad hoc coalition position } \\
& $(1)$ & $(2)$ & $(3)$ & $(4)$ \\
\hline Policy score & 1.23 & -2.00 & -1.89 & -1.91 \\
& $(0.77)$ & $(1.25)$ & $(1.34)$ & $(1.54)$ \\
Democratic 2016 presidential vote & & $9.76^{* * *}$ & $8.56^{* * *}$ & $11.26^{* * *}$ \\
& & $(3.08)$ & $(3.23)$ & $(4.03)$ \\
Control of state government & & 0.39 & 0.28 & 0.10 \\
& & $(0.40)$ & $(0.42)$ & $(0.45)$ \\
Utility-level covariates & & & $\checkmark$ & $\checkmark$ \\
State-level covariates & & & & $\checkmark$ \\
\hline Observations & 136 & 136 & 136 & 136 \\
\hline \hline
\end{tabular}

Coefficients from ordinal logistic regression model with three levels: oppose, neutral, and support. Robust standard errors clustered at parent company level. ${ }^{*} \mathrm{p}<.1{ }^{* *} \mathrm{p}<.05 * * * \mathrm{p}<.01$.

Table A7: The effects of state policy and politics on coalitions in favor of climate action minus coalitions opposed (OLS)

Supportive minus opposing coalitions

\begin{tabular}{lcccc} 
& $(1)$ & $(2)$ & $(3)$ & $(4)$ \\
\hline Policy score & $1.41^{* *}$ & -1.03 & -0.56 & 0.07 \\
& $(0.60)$ & $(1.11)$ & $(1.09)$ & $(1.23)$ \\
Democratic 2016 presidential vote & & $10.44^{* * *}$ & $7.89^{* * *}$ & $8.95^{* * *}$ \\
& & $(2.64)$ & $(2.64)$ & $(3.17)$ \\
Control of state government & & -0.23 & -0.32 & -0.35 \\
& & $(0.35)$ & $(0.34)$ & $(0.36)$ \\
Utility-level covariates & & & $\checkmark$ & $\checkmark$ \\
State-level covariates & 159 & 159 & 159 & $\checkmark$ \\
\hline Observations & & & & \\
\hline \hline
\end{tabular}

Coeffients from OLS, with outcome as membership in pro-climate coalitions less membership in anti-climate coalitions. Robust standard errors clustered at parent company level. ${ }^{*} \mathrm{p}<.1{ }^{* *} \mathrm{p}<.05{ }^{* * *} \mathrm{p}<.01$.

A.5: Full regression results

Table A8: The effects of state policy and politics CPP litigation, full regression results 


\begin{tabular}{|c|c|c|c|c|}
\hline & (1) & $(2)$ & (3) & (4) \\
\hline State policy score & $\begin{array}{c}4.01^{* * *} \\
(0.98)\end{array}$ & $\begin{array}{l}2.55^{*} \\
(1.43)\end{array}$ & $\begin{array}{c}4.11^{* * *} \\
(1.71)\end{array}$ & $\begin{array}{l}4.48^{* *} \\
(2.12)\end{array}$ \\
\hline Democratic 2016 presidential vote & & $\begin{array}{c}0.65 \\
(3.40)\end{array}$ & $\begin{array}{l}-0.55 \\
(3.48)\end{array}$ & $\begin{array}{l}-2.38 \\
(4.35)\end{array}$ \\
\hline State government position & & $\begin{array}{c}0.62 \\
(0.38)\end{array}$ & $\begin{array}{c}0.40 \\
(0.44)\end{array}$ & $\begin{array}{c}0.36 \\
(0.41)\end{array}$ \\
\hline Percent coal & & & $\begin{array}{l}-0.59 \\
(0.87)\end{array}$ & $\begin{array}{l}-0.65 \\
(0.90)\end{array}$ \\
\hline Percent non-CO2 & & & $\begin{array}{l}1.83^{* *} \\
(0.81)\end{array}$ & $\begin{array}{l}1.77^{* *} \\
(0.86)\end{array}$ \\
\hline Generation capacity (logged MW) & & & $\begin{array}{l}-0.02 \\
(0.08)\end{array}$ & $\begin{array}{c}0.01 \\
(0.08)\end{array}$ \\
\hline Sales (logged Mwh) & & & $\begin{array}{c}0.05^{*} \\
(0.03)\end{array}$ & $\begin{array}{l}0.06^{* *} \\
(0.03)\end{array}$ \\
\hline Public utility & & & $\begin{array}{c}2.97^{* * *} \\
(1.00)\end{array}$ & $\begin{array}{c}3.08^{* * *} \\
(1.01)\end{array}$ \\
\hline GDP per capita & & & & $\begin{array}{c}0.03 \\
(0.04)\end{array}$ \\
\hline Tax revenue per capita & & & & $\begin{array}{l}-0.50 \\
(0.42)\end{array}$ \\
\hline Wind potential & & & & $\begin{array}{c}-0.02 \\
(0.03)\end{array}$ \\
\hline Air quality & & & & $\begin{array}{l}-0.04 \\
(0.05)\end{array}$ \\
\hline Unemployment & & & & $\begin{array}{c}-0.43 \\
(0.38)\end{array}$ \\
\hline Electricity prices & & & & $\begin{array}{c}0.05 \\
(0.04)\end{array}$ \\
\hline Observations & 159 & 159 & 159 & 159 \\
\hline
\end{tabular}

Coefficients from ordinal logistic regression model with three levels: oppose, no action, and support. Robust standard errors clustered at parent company level. ${ }^{*} \mathrm{p}<.1{ }^{* *} \mathrm{p}<.05 * * * \mathrm{p}<.01$.

Table A9: The effects of state policy and politics on climate ad hoc coalitions, full regression results 


\begin{tabular}{|c|c|c|c|c|}
\hline & \multicolumn{4}{|c|}{ Ad hoc coalition membership } \\
\hline & (1) & $(2)$ & (3) & (4) \\
\hline Policy score & $\begin{array}{c}1.24 \\
(0.77)\end{array}$ & $\begin{array}{c}-2.01^{*} \\
(1.02)\end{array}$ & $\begin{array}{l}-1.54 \\
(1.17)\end{array}$ & $\begin{array}{l}-1.59 \\
(1.46)\end{array}$ \\
\hline Democratic 2016 presidential vote & & $\begin{array}{c}10.12^{* * *} \\
(3.19)\end{array}$ & $\begin{array}{c}8.12^{* * *} \\
(3.23)\end{array}$ & $\begin{array}{c}10.40^{* * *} \\
(4.09)\end{array}$ \\
\hline Control of state government & & $\begin{array}{c}0.33 \\
(0.41)\end{array}$ & $\begin{array}{c}0.17 \\
(0.42)\end{array}$ & $\begin{array}{l}-0.05 \\
(0.43)\end{array}$ \\
\hline Percent coal & & & $\begin{array}{c}-2.92^{* * *} \\
(0.79)\end{array}$ & $\begin{array}{c}-3.20^{* * *} \\
(0.85)\end{array}$ \\
\hline Percent non-CO2 & & & $\begin{array}{l}-0.18 \\
(0.64)\end{array}$ & $\begin{array}{l}-0.45 \\
(0.68)\end{array}$ \\
\hline Generation capacity (logged MW) & & & $\begin{array}{l}0.15^{* *} \\
(0.07)\end{array}$ & $\begin{array}{l}0.16^{* *} \\
(0.07)\end{array}$ \\
\hline Sales (logged Mwh) & & & $\begin{array}{c}0.01 \\
(0.02)\end{array}$ & $\begin{array}{c}0.01 \\
(0.02)\end{array}$ \\
\hline Public utility & & & $\begin{array}{c}0.50 \\
(0.66)\end{array}$ & $\begin{array}{c}0.70 \\
(0.67)\end{array}$ \\
\hline GDP per capita & & & & $\begin{array}{l}-0.02 \\
(0.03)\end{array}$ \\
\hline Tax revenue per capita & & & & $\begin{array}{c}0.42 \\
(0.37)\end{array}$ \\
\hline Wind potential & & & & $\begin{array}{c}0.04 \\
(0.02)\end{array}$ \\
\hline Air quality & & & & $\begin{array}{l}-0.05 \\
(0.04)\end{array}$ \\
\hline Unemployment & & & & $\begin{array}{c}0.10 \\
(0.32)\end{array}$ \\
\hline Electricity prices & & & & $\begin{array}{c}0.02 \\
(0.03) \\
\end{array}$ \\
\hline Observations & 159 & 159 & 159 & 159 \\
\hline
\end{tabular}

Coefficients from ordinal logistic regression model with three levels: oppose, neutral, and support. Robust standard errors clustered at parent company level. ${ }^{*} \mathrm{p}<.1 * * \mathrm{p}<.05 * * * \mathrm{p}<.01$. 